\title{
A New Null Matrix Electrochemical Cell for Rietveld Refinements of in-situ or operando neutron powder diffraction data
}

\author{
M. Bianchini ${ }^{1,2,3,4}$, J. B. Leriche ${ }^{1,4}$, J.-L. Laborier ${ }^{2}$, L. Gendrin², \\ E. Suard ${ }^{2}$, L. Croguennec ${ }^{3,4}$ and C. Masquelier ${ }^{1,4, *}$ \\ ${ }^{1}$ Laboratoire de Réactivité et de Chimie des Solides, \\ CNRS-UMR\#7314, Université de Picardie Jules Vernes, 80039 Amiens Cedex 1, France \\ ${ }^{2}$ Institut Laue-Langevin, 6 rue Jules Horowitz, 38000 Grenoble, France \\ ${ }^{3}$ CNRS, Univ. Bordeaux, ICMCB, UPR 9048, F-33600 Pessac, France \\ ${ }^{4}$ RS2E, Réseau Français sur le Stockage Electrochimique de l'Energie, FR CNRS\#3459 \\ 33 Rue Saint-Leu, 80039 Amiens Cedex 1, France
}

\begin{abstract}
In-situ techniques proved to be exceptionally useful tools to understand electrode materials for Li-ion batteries. In-situ neutron diffraction (ND) knew a slow development, due to the intrinsic difficulties it held. We have designed a new electrochemical cell, manufactured with a completely neutron-transparent (Ti,Zr) alloy. Such a cell is able to combine, for the first time, good electrochemical properties and the ability to collect neutron diffraction patterns operando, with good statistics and no other Bragg peaks than those of the electrode material of interest. This allows detailed structural determinations of electrode materials by Rietveld refinement during operation. First case studies hereby reported are the olivine $\mathrm{LiFePO}_{4}$ and the overstoichiometric spinel $\mathrm{Li}_{1.1} \mathrm{Mn}_{1.9} \mathrm{O}_{4}$, investigated at the D20 diffractometer of ILL (Grenoble), and compared to pure powder patterns obtained from the high-resolution D2B diffractometer. These studies demonstrate the feasibility and reliability of such experiments and open the field to a wide range of investigations on battery electrode materials.
\end{abstract}

Keywords: Neutron diffraction, in-situ, operando, Rietveld refinement, lithium batteries, D20 diffractometer, $\mathrm{LiFePO}_{4}, \mathrm{LiMn}_{2} \mathrm{O}_{4}$. 


\section{Introduction}

In the last decade the quest to improve Li-ion and Na-ion batteries followed a great number of different paths (1). Not only new materials were looked for and designed, but also analysis techniques were developed and improved considerably to allow scientists to unravel the electrochemical cycling mechanisms. In-situ techniques, in particular, proved to be exceptionally useful tools to understand such behaviors which are dynamical in nature and whose comprehension is limited if they are only looked at through a series of snapshots, such as those we can get from ex-situ studies. X-ray diffraction, in particular, has been the leading technique thanks to the possibility to exploit laboratory diffractometers (2-5), as well as more powerful synchrotrons (6-8). Many studies have been published and their importance is noteworthy. On the other hand, the in-situ principle has been applied to other techniques, such as Raman spectroscopy $(9), \operatorname{XANES}(7,10,11)$, NMR $(12,13)$ Mössbauer (14-17) etc.

Until 15 years ago, the Neutron diffraction (ND) technique was not considered for in-situ (during electrochemical cycling reactions) studies on lithium batteries, because of the intrinsic difficulties it held. However, the advantages of ND compared to XRD are not to be neglected. Indeed electrode materials often have a stoichiometry involving light elements such as lithium and oxygen, almost transparent to X-Rays (18). Moreover, many of these materials include more than one transition metal element $(\mathrm{Mn}, \mathrm{Co}, \mathrm{Ni}, \ldots)$ and it is of great difficulty to distinguish them using X-Rays because of their similar scattering powers, while neutrons' scattering length does not vary continuously through the periodic table (and it can be negative) (19). Hence, a much higher contrast between such elements may be attained using ND and such advantages have been the engine to push for the development of in-situ ND. On the other hand, some drawbacks are evident: first of all, a neutron source is less easy to have at hand. Secondly, Li-batteries include many problematic components such as hydrogen-rich electrolytes that create a strong continuous background, natural lithium that absorbs neutrons and many other parts giving rise to very intense Bragg peaks such as aluminum/copper current collectors, steel protective cases etc. For these reasons in-situ ND took much more time to be developed and neutron diffraction facilities, worldwide, that can provide the necessary flux and resolution for such kind of investigations are still rare. 
The fabrication of custom-made electrochemical cells was a mandatory requirement and first interesting attempts were reported around 2000 by different groups (20-24). The challenge that such cells had to face consisted in combining a good electrochemistry with good statistics for neutron diffraction, knowing that the two requirements often conflict, e.g. a big amount of powder for the positive electrode is required for ND, while this is usually problematic for an homogeneous electrochemistry. At that time, the results did not match expectations and improved cell designs were reported by the group of P. Novak at PSI (Switzerland) $(25,26)$. More recently it became clear that even commercially available lithium batteries could be studied with in-situ ND (27-31) giving interesting information on their overall behavior and showing that their patterns are not worse than those of the early custom made-cells. Finally, very recently, two improved cells were designed by the groups of Novak (PSI Switzerland) and Gustaffson (Univ. Uppsala, Sweden) in such a way to combine most of the required aspects for in-situ ND $(32,33)$ : adequate geometry for diffraction and reliable electrochemistry.

However, up to now and to the best of our knowledge, all the reported in-situ ND data still suffered from poor reliability of the attempted Rietveld refinements, due to the presence of high background (due to the electrolyte) and many additional diffraction peaks besides those of the studied electrode material, arising from the cell itself (current collectors, casing, graphite, ...). In such cases, we think that it is almost impossible to perform a good quality multi-phase pattern refinement.

In this paper we present a custom-made cell for in-situ and operando neutron diffraction that was developed with specific requirements:

being able to cycle electrochemically for tens of cycles at $C / 5$ for loadings of electrode materials comprised between $10 \mathrm{mg}$ and $200 \mathrm{mg}$,

being easy to use, wash and re-use for potential users in large scale facilities, providing a good quality neutron powder diffraction pattern in $\mathbf{3 0}$ min or less with no contributions besides those of the electrode material under study.

The successful development of such cell is presented here and especially illustrated with the operando investigation of $\mathrm{Li}^{+}$extraction from the positive electrode material $\mathrm{LiFePO}_{4}$ in a Lithium battery. 


\section{Experimental}

For the electrochemistry within the designed insitu cell, the chosen active material was mixed with an appropriate amount of Carbon Super $\mathrm{P}\left(10 \%\right.$ for $\mathrm{Li}_{1.1} \mathrm{Mn}_{1.9} \mathrm{O}_{4}$ and $12 \%$ for $\left.\mathrm{LiFePO}_{4}\right)$ and the electrode mixture was ground in a mortar. No binder was used so as to avoid the coherent and incoherent scattering it would generate. Batteries were assembled with glass fiber separators and either the commercial LP30 electrolyte (SelectiLyte ${ }^{\mathrm{TM}}$, Merck company, 1M $\mathrm{LiPF}_{6}$ in EC:DMC (1:1) (wt\%)) or a home-made deuterated electrolyte (1M LiPF 6 (Sigma Aldrich) in d-Ethylene Carbonate : d-Dimethyl Carbonate 1:4 wt\% (Armar Chemicals)). Lithium metal was used as anode. Details about each electrochemical cycling are given in the result and discussion section.

Regarding neutron diffraction, pure pristine powders (> $1 \mathrm{~g}$ ) of $\mathrm{Li}_{1.1} \mathrm{Mn}_{1.9} \mathrm{O}_{4}$ and $\mathrm{LiFePO}_{4}$ were measured for 4 hours each inside vanadium cylindrical containers on the high-resolution D2B diffractometer at Institut Laue-Langevin (ILL, Grenoble). The wavelength was refined to be $1.594 \AA$ A thanks to a NAC standard.

In-situ and operando measurements were performed on the D20 high-flux diffractometer at ILL at a wavelength refined as $1.547 \AA$ thanks to a Silicon standard. During galvanostatic charge, neutron diffraction patterns were recorded. Measurement time varied and is discussed in detail later on. Neutron diffraction patterns were analyzed thanks to the Rietveld method using the FULLPROF suite.

\section{Results and discussion}

\section{1) Design of an efficient Ti/Zr-based electrochemical cell}

The designed electrochemical cell for in-situ or operando neutron diffraction is schematized in figure 1. 
The heart of the cell is the powder container, highlighted in blue, which hosts the powder electrode material (negative or positive electrode). Peculiar care was taken in choosing an alloy and manufacturing a cell that would not be oxidized / reduced electrochemically while being transparent to the neutron beam. A Ti-Zr alloy ( $\left.{ }^{T_{2}} i_{2.08} \mathrm{Zr}\right)$, well known from the neutron diffraction community in Grenoble as a so-called "null matrix material", was chosen (34). Titanium and Zirconium have indeed scattering lengths opposite in sign and in a 1:2 ratio ( $b_{T i}$ $=-3.3710^{-12} \mathrm{~cm}$ and $b_{z r}=7.1610^{-12} \mathrm{~cm}$ ) and their alloy, prepared with the corresponding necessary stoichiometric amounts of the two elements, has zero overall scattering intensity, thus being a perfect container material for ND. Furthermore, it is a good current conductor and it does not get easily oxidized, making the cell resistant mechanically and chemically. The volume of the corresponding cylindrical container is approximately $9 \mathrm{~cm}^{3}\left(h^{*} \pi \cdot R^{2} \approx 3^{*} \pi^{*} 1^{2}\right)$. When placed in this container, $200 \mathrm{mg}$ of the powder electrode to be investigated occupy $\sim 1 \mathrm{~mm}$ in height, to be exposed to the neutron beam.

All the other elements of the battery are subsequently assembled and stacked. First a glassfiber separator is inserted and soaked in the electrolyte; the negative part of the cell is then built, comprising Li metal as the counter electrode, a $1 \mathrm{~mm}$ thick $\mathrm{Ti}_{2.08} \mathrm{Zr}$ disk acting as the negative current collector, a spring to create pressure on the powder and a plunger to close the cell. A mylar film covers the internal part of the in-situ cell and together with a plastic gasket assures the electrical insulation between the positive and the negative electrode and makes the cell air-tight. Finally, a screw is used to close the cell and maintain the pressure on the powder. Once closed, the cell can be mounted (vertically) in the diffractometer as illustrated in figure 1 thanks to a plastic screw entering the top of the plunger, and aligned with slits so that the beam irradiates only the bottom part of the cell where the electrode powder is located.

\section{2) High quality electrochemistry obtained within the electrochemical cell designed for in-situ and operando neutron diffraction}

The electrochemical performances of the cell were tested with commercially available positive electrode materials: an olivine-type phase $\mathrm{LiFePO}_{4}(35)$ and an over-stoichiometric spinel-type phase $\mathrm{Li}_{1.1} \mathrm{Mn}_{1.9} \mathrm{O}_{4}$ (36). The first, 16 years after its discovery, has now reached commercial 
exploitation and, although its basic crystal structure is well-known $(37,38)$, it keeps attracting much attention thanks to the versatility of its electrochemical properties depending for instance on temperature, particle size, carbon coating, etc. $(10,39-42)$. The second, a spineltype material " $\mathrm{LiMn}_{2} \mathrm{O}_{4}$ ", has also been investigated for more than two decades as a positive electrode material for Li-ion batteries $(36,43-49)$ and its electrochemical properties are strongly dependent to the lithium content, as slightly over-stoichiometric "Li-rich" $\left(\mathrm{Li}_{1+\delta} \mathrm{Mn}_{2-}\right.$ $\left.{ }_{\delta} \mathrm{O}_{4}\right)$ or under-stoichiometric "cation-poor" $\left(\mathrm{Li}_{1-\delta^{\prime}} \mathrm{Mn}_{2-2 \delta^{\prime}} \mathrm{O}_{4}\right)$ samples would imply changes in the oxidation state of $\mathrm{Mn}$ and thus in the available capacity or cycling properties (43).

Each LiFePO 4 or $\mathrm{Li}_{1.1} \mathrm{Mn}_{1.9} \mathrm{O}_{4}$ powder was mixed with appropriate amounts of Carbon Super $\mathrm{P}$ to improve the electrical conductivity of the electrode and the batteries were prepared with either the commercial electrolyte LP30 or a home-made deuterated electrolyte (see experimental section). Previous studies had indeed shown that the background coming from the hydrogen-rich standard electrolyte is too high to obtain good-quality ND patterns (32). For this reason a deuterated electrolyte was prepared and tested, its composition chosen as a compromise between satisfactory properties and a minimization of its price.

The upper panel of figure 2 illustrates the electrochemical data obtained within the in-situ electrochemical cell for i) $213 \mathrm{mg}$ of $\mathrm{Li}_{1.1} \mathrm{Mn}_{1.9} \mathrm{O}_{4}$ cycled at $\mathrm{C} / 16(1.77 \mathrm{~mA})$ and ii) $19 \mathrm{mg}$ at $\mathrm{C} / 4$ $(0.63 \mathrm{~mA})$. Only the first two cycles are depicted here but subsequent prolonged cycling with good coulombic efficiency under these conditions were achieved. In both cases, the observed polarization of the cell ( $\Delta \mathrm{V} \sim 175 \mathrm{mV}$ between charge and discharge) is quite satisfactory. The observed irreversible capacity loss and capacity decay at higher current is mostly due to the absence of binder within the electrode and to the electrolyte itself, not ideal for high rate applications. The derivative curves $\mathrm{dV} / \mathrm{dx}$ display typical behaviors of over-stoichiometric spinel-type $\mathrm{Li}_{1+\delta} \mathrm{Mn}_{2-\delta} \mathrm{O}_{4}$ positive electrode materials, with two redox processes around $4 \mathrm{~V}$ vs. $\mathrm{Li}^{+} / \mathrm{Li}$ and the deintercalation of $0.6 \mathrm{Li}^{+}$during the first charge, which is in rather good agreement with the stoichiometry of the material (maximum theoretical capacity is expected to correspond to $0.70 \mathrm{Li}^{+}$) and an average oxidation state of +3.63 for $\mathrm{Mn}$. Similar highly reliable and reproducible electrochemical data were obtained from $\mathrm{LiFePO}_{4}$ electrodes, as depicted figure $\mathbf{2 b}$. The voltage plateau observed around $3.45 \mathrm{~V} \mathrm{vs.} \mathrm{Li}^{+} / \mathrm{Li}$ reveals as expected a classical two-phase electrochemical reaction between $\mathrm{Li}_{1-\delta} \mathrm{FePO}_{4}$ and $\mathrm{Li}_{\varepsilon} \mathrm{FePO}_{4}$ (50). These 
data show, additionally, that the deuterated electrolyte we used possessed similar properties (although slightly lower kinetics) than a standard EC:DMC-based one (LP30) at cycling rates as high as $\mathrm{C} / 10$. Additionally, only small capacity loss was observed (at smaller regime) for higher electrode loadings ( $105 \mathrm{mg}$ ).

The electrochemical cell designed to obtain in-situ or operando neutron diffraction data was thus shown to deliver electrochemical performances comparable to those obtained in classical electrochemical cells, with an active mass that can be rather large $(>200 \mathrm{mg})$ and a cycling rate that can be rather fast $(\mathrm{C} / 4)$.

\section{3) Rietveld quality data obtained for pristine materials within the electrochemical in-situ TiZr cell}

The next challenge was to prove that Rietveld refinement of neutron diffraction data obtained for powders placed within the electrochemical cell and in full battery configuration was possible and could lead to structural determinations similar to those performed from high resolution neutron diffraction data obtained on powder alone. For each of the two materials, $\mathrm{LiFePO}_{4}$ and $\mathrm{Li}_{1.1} \mathrm{Mn}_{1.9} \mathrm{O}_{4}$, neutron diffraction patterns were collected under various configurations and illustrative examples are gathered in figure $\mathbf{3}$.

The neutron diffraction patterns displayed in the top part of figure $\mathbf{3}$ were recorded within 4 hours on the high-resolution diffractometer D2B $(\lambda=1.594 \AA)$ of ILL for pure pristine $\mathrm{Li}_{1.1} \mathrm{Mn}_{1.9} \mathrm{O}_{4}$ and $\mathrm{LiFePO}_{4}$ powders.

The neutron diffraction patterns displayed in the bottom part of figure $\mathbf{3}$ were recorded on the high-flux diffractometer D20 $(\lambda=1.547 \AA)$ of ILL for $\approx 200 \mathrm{mg}$ of $\mathrm{Li}_{1.1} \mathrm{Mn}_{1.9} \mathrm{O}_{4}$ (30 minutes pattern) and $\mathrm{LiFePO}_{4}$ (one hour pattern) electrodes placed within the in-situ cell together with the deuterated electrolyte, the separator, the negative electrode, the current collector, i.e. in full-operational battery configuration. Note that the diffractometer configuration chosen for the in-situ experiments was a compromise between the highest possible flux and the best resolution, leading to a wavelength refined as $1.547 \AA$. It should also be observed that the raw data were 
recorded as 10 minutes scans. In figure 3 and in the following of this paper, we chose to sum them ( 3 by 3 for $\mathrm{Li}_{1.1} \mathrm{Mn}_{1.9} \mathrm{O}_{4}$ and 6 by 6 for $\mathrm{LiFePO}_{4}$ ) so as to obtain better statistics. For $\mathrm{LiFePO}_{4}$, however, 30 minutes scans were also a possible choice, since reliable refinements could be obtained on 30 minutes scans as well. A table with the refined parameters for $30 \mathrm{~min}$ and 1 hour patterns is reported in the supporting information (Table S1).

All the diffraction patterns were refined by the Rietveld method (51), i.e. with the determination of the cell parameters, the atomic positions, the occupancy factors and the isotropic atomic displacement parameters, thanks to the FullProf suite (52). The similar wavelengths are helpful for a straight comparison of peaks intensities of the collected ND patterns since they are approximately at the same angular position. The "in-situ" patterns show a large bump in the low-angle region (15-30 degrees) due to the scattering from the deuterated electrolyte (and not from the glass fiber separator) that was taken into account by a point by point background definition. However, it is remarkable to note that neutron diffraction allows obtaining high intensity diffraction peaks at high angles ( $>100^{\circ}$ in $\left.2 \theta\right)$. As shown by the results given in figure $\mathbf{3}$ (good minimization of the difference between the observed and calculated data) and by the good reliability factors given in Tables $\mathbf{1}$ and $\mathbf{2}$, single phase data refinements of positive electrode materials can be achieved within a Lithium based electrochemical cell. The obtained structural parameters are listed in Tables 1-3 and match very well with those obtained from high resolution data.

$\mathrm{Li}_{1.1} \mathrm{Mn}_{1.9} \mathrm{O}_{4}$ has a cubic spinel-type structure (space group $\mathrm{Fd}-3 \mathrm{~m}$ ), with a cell parameter $\left(8.2187(1) \AA\right.$ ) significantly smaller than that of stoichiometric $\mathrm{LiMn}_{2} \mathrm{O}_{4}(8.248 \AA$ (43)). It is typical of Li-rich spinel compositions $\mathrm{Li}_{1+\delta} \mathrm{Mn}_{2-\delta} \mathrm{O}_{4}$ with $\delta \sim 0.1$ as tabulated in $(43,49)$. The refined crystal structure of the $\mathrm{Li}_{1.1} \mathrm{Mn}_{1.9} \mathrm{O}_{4}$ powder we used agrees remarkably well with this proposed stoichiometry as the $\mathrm{Li} / \mathrm{Mn}$ distribution onto the octahedral site was refined to 0.07(6)/1.92(6) (Table 1). This result, correlated with inductively coupled plasma atomic emission spectroscopy (ICP-AES) led us to the global formula $\mathrm{Li}_{1.1} \mathrm{Mn}_{1.9} \mathrm{O}_{4}$ for the powder we investigated. The corresponding average oxidation state for $\mathrm{Mn}$ is therefore 3.63+, which indicates that, theoretically, only $0.7 \mathrm{Li}^{+}$can be extracted up to $\mathrm{Li}_{0.4} \mathrm{Mn}_{1.9} \mathrm{O}_{4}$. $\mathrm{Li}$ lies in tetrahedral (8a) sites with Li-O distances of 1.967(1) $\AA$ and Mn in octahedral (16d) sites with 
Mn-O distance of 1.953(1) A. As shown in Table 1, the structural parameters determined for $\mathrm{Li}_{1.1} \mathrm{Mn}_{1.9} \mathrm{O}_{4}$ from neutron diffraction data obtained in the in-situ lithium cell on the diffractometer D20 are in very good agreement with those obtained for the pure powder on the high resolution diffractometer D2B.

$\mathrm{LiFePO}_{4}$ belongs to the olivine-type structural family, described in an orthorhombic unit cell (space group $\mathrm{P}_{\mathrm{nma}}$ ) with $\mathrm{a}=10.3233(2) \AA, b=6.0044(1) \AA$ and $c=4.6918(1) \AA$. The structure is built on layers of corner-sharing distorted $\mathrm{FeO}_{6}$ octahedra linked through $\mathrm{PO}_{4}$ tetrahedra and with tunnels along the $\mathrm{b}$ and $\mathrm{c}$ axes where $\mathrm{Li}^{+}$ions occupy octahedral oxygen environments. As shown in Tables $\mathbf{2}$ and $\mathbf{3}$ the structural parameters determined for $\mathrm{LiFePO}_{4}$ considering the neutron diffraction data recorded within the in-situ electrochemical cell on the diffractometer D20 are in very good agreement with those obtained for the pure powder on the high resolution diffractometer D2B: the cell parameters, atomic positions, distances and distortions of the $\mathrm{FeO}_{6}, \mathrm{PO}_{4}$ and $\mathrm{LiO}_{6}$ polyhedra are indeed very similar for the two sets of data.

We have thus proved that neutron diffraction data obtained in the electrochemical cell designed for in-situ or operando experiments are of sufficient quality to determine structures and thus to get more insight into structural changes occurring upon cycling.

\section{4) In-situ neutron diffraction}

Lithium batteries were prepared using $\mathrm{LiFePO}_{4}$ as follows: $200 \mathrm{mg}$ of $\mathrm{LiFePO}_{4}+\mathrm{Csp}(88: 12 \mathrm{wt} \%)$ // deuterated electrolyte (1M LiPF 6 in d-EC : d-DEC 1:4 wt\%) // lithium metal. The cell was cycled at $\mathrm{C} / 24$ rate and then kept for 1 hour at the maximum potential of $4.1 \mathrm{~V} \mathrm{vs.} \mathrm{Li}^{+} / \mathrm{Li}$; neutron diffraction patterns were recorded every 10 minutes during the charge and the floating. Figure 4 shows the operando neutron diffraction data, i.e. 1 hour patterns corresponding to the sum of 6 successive 10 minutes patterns, and the corresponding charge curve. Each 1 hour pattern corresponds to $\Delta x=1 / 24=0.042$.

The electrochemical process can be clearly observed to be a two-phase reaction from the right beginning, with the disappearance of the initial $\mathrm{LiFePO}_{4}$ phase whereas the end member phase 
$\mathrm{FePO}_{4}$ is forming continuously, in agreement with the obtained electrochemical curve, which is absolutely flat. The initial pattern (black) corresponds to that of figure $\mathbf{3}$ (bottom), i.e. a 1 hour scan on the pristine material before cycling. The other end member (red) corresponds to $\mathrm{FePO}_{4}$, which appears as a single phase from neutron diffraction despite a global composition for the positive electrode of $\sim \mathrm{Li}_{0.08} \mathrm{FePO}_{4}$ at the end of the charge. Its neutron diffraction pattern was recorded during 1 hour at a constant potential of $4.1 \mathrm{~V} \mathrm{vs.} \mathrm{Li}^{+} / \mathrm{Li}$. Between these two end member patterns, the patterns highlighted correspond to global compositions close to $3 / 4 \mathrm{LiFePO}_{4}: 1 / 4 \mathrm{FePO}_{4}$ (blue), 1/2 $\mathrm{LiFePO}_{4}: 1 / 2 \mathrm{FePO}_{4}$ (green) and 1/4 $\mathrm{LiFePO}_{4}: 3 / 4 \mathrm{FePO}_{4}$ (brown). Rietveld refinements were performed for all the (1-x) $\mathrm{LiFePO}_{4}$. $x \mathrm{FePO}_{4}$ compositions with high quality fittings, as illustrated in figure 5 for these 3 selected compositions and for the two end members $\mathrm{LiFePO}_{4}$ and $\mathrm{FePO}_{4}$. Importantly, note that we closely checked, for the first series of diffraction patterns (recorded every 10') recorded during charge, that the unit cell parameters of $\mathrm{LiFePO}_{4}$ remained absolutely constant and for the last diffraction patterns that the unit-cell parameters of $\mathrm{FePO}_{4}$ remained constant as well. Therefore, the overall reaction may really be regarded as a two phase reaction between $\mathrm{LiFePO}_{4}$ and $\mathrm{FePO}_{4}$, contrary to what observed by Yamada et al. (40) for nano-sized LiFePO 4 .

For each of the two end members, 15 parameters have been refined: the scale factor, 3 cell parameters and 11 fractional atomic coordinates. Zero shift and wavelength had been previously refined thanks to an internal standard. Isotropic thermal displacement parameters were instead kept fixed to the values obtained for the pattern measured on $\mathrm{D} 2 \mathrm{~B}$ for $\mathrm{LiFePO}_{4}$. Besides, the absorption coefficient $\mu \mathrm{R}$ had to be considered due to the presence of lithium. It had thus its maximum value for $\mathrm{LiFePO}_{4}$ (about 0.43) and it was negligible for $\mathrm{FePO}_{4}$. In the case of the three intermediate two-phase compositions, the refined parameters were still 15 for each phase, making a total of 30 for each pattern. The coefficient $\mu \mathrm{R}$ was then reduced according the weight percent of $\mathrm{LiFePO}_{4}$ remaining in the structure. The main structural results coming from this analysis are reported in Table 3, where the good quality of the refinement can be seen from $R_{\text {Bragg }}$ parameters, never exceeding $10.6 \%$, and bond length distances in agreement for a given phase between the different compositions. Refined values are slightly inaccurate only when the crystalline weight of the considered phase is around $25 \%$ or less. Moreover, bond length distances for $\mathrm{LiFePO}_{4}$ and $\mathrm{FePO}_{4}$ can be compared to those reported in literature (53) showing a good agreement. 
A sequential refinement of the operando diffraction patterns was also performed, involving all the recorded patterns. In this case the structural parameters were fixed and only scale factors were permitted to vary. This allowed determining weight fractions for $\mathrm{LiFePO}_{4}$ and $\mathrm{FePO}_{4}$, within the crystalline part of all the compositions studied. Indeed, as shown by the results given in figure $6, \mathrm{FePO}_{4}$ is not detected at the very beginning of the charge, as happens to $\mathrm{LiFePO}_{4}$ at the end of the charge. Note that it does not mean that these minority phases are effectively not present, but their crystalline domains could be small and not extended enough to diffract efficiently. Then, the distribution between $\mathrm{LiFePO}_{4}$ and $\mathrm{FePO}_{4}$ does not follow exactly the theoretical line, although a linear variation is expected for a two-phase reaction. This is well explained by: i) a quantification that is in fact only semi-quantitative due to the absence of an internal standard with a known fraction (versus $\mathrm{LiFePO}_{4}$ ) in our positive electrode and thus to the impossibility to take into account the possible presence of noncrystalline phases (54) and ii) the strong absorption of $\mathrm{Li}$ which is present in one phase, $\mathrm{LiFePO}_{4}$, and not in the other one, $\mathrm{FePO}_{4}$, affecting thus also slightly the ratio between the two weight fractions. Such a deviation from the theoretical behavior had also been observed before by Andersson and Thomas (38). Despite of that, the change in the weight fractions between $\mathrm{LiFePO}_{4}$ and $\mathrm{FePO}_{4}$ is still quite close to a linear behavior, as an additional proof for the quality of the analysis of these in-situ neutron diffraction data.

\section{Conclusions}

We have hereby presented an electrochemical cell for in-situ and operando neutron diffraction, thanks in particular to the choice of a neutron-transparent material such as the $\mathrm{Ti} / \mathrm{Zr}$ alloy. For two representative electrode materials, namely $\mathrm{Li}_{1.1} \mathrm{Mn}_{1.9} \mathrm{O}_{4}$ and $\mathrm{LiFePO}_{4}$, electrochemical curves with different peculiarities are shown. Subsequently, in-situ ND measurements were conducted in charge on the D20 diffractometer of ILL Grenoble. For the first time a single-phase Rietveld refinement could be successfully performed on in-situ and operando patterns, leading to reliable structure parameters. For these reasons, such a cell can be an extremely useful tool to study new materials of interest for $\mathrm{Li}$-ion and $\mathrm{Na}$-ion batteries, 
where the understanding of phase transition mechanisms is essential for further improvements and development.

\section{Acknowledgements}

The authors would like to gratefully acknowledge Thomas Hansen and Juan Rodriguez-Carvajal (ILL-Grenoble) for help and fruitful discussions, ILL for the time granted on D2B and D20, Fannie Alloin (LEPMI-Grenoble) for her kind help and expertise in the deuterated electrolytes' preparation and Charlotte Beebee and Annalisa Boscaino (ILL-Grenoble) for their kind sharing of potentiostat workstation and D20 beamtime, respectively. LC acknowledges the financial support of Région Aquitaine. 


\section{References}

1. M. Armand and J. M. Tarascon, Nature, 451, 652 (2008).

2. A. S. Andersson, B. Kalska, L. Haggstrom and J. O. Thomas, Solid State lonics, 130, 41 (2000).

3. M. Morcrette, Y. Chabre, G. Vaughan, G. Amatucci, J. B. Leriche, S. Patoux, C. Masquelier and J. M. Tarascon, Electrochim. Acta, 47, 3137 (2002).

4. T. Gustafsson, J. O. Thomas, R. Koksbang and G. C. Farrington, Electrochim. Acta, 37, 1639 (1992).

5. J. R. Dahn and R. R. Haering, Solid State Communications, 40, 245 (1981).

6. V. R. Albertini, P. Perfetti, F. Ronci, P. Reale and B. Scrosati, Applied Physics Letters, 79, 27 (2001).

7. J. B. Leriche, S. Hamelet, J. Shu, M. Morcrette, C. Masquelier, G. Ouvrard, M. Zerrouki, P. Soudan, S. Belin, E. Elkaim and F. Baudelet, Journal of The Electrochemical Society, 157, A606 (2010).

8. G. Ouvrard, M. Zerrouki, P. Soudan, B. Lestriez, C. Masquelier, M. Morcrette, S. Hamelet, S. Belin, A. M. Flank and F. Baudelet, Journal of Power Sources, 229, 16 (2013).

9. W. W. Huang and R. Frech, Journal of Power Sources, 81, 616 (1999).

10. Y. Orikasa, T. Maeda, Y. Koyama, H. Murayama, K. Fukuda, H. Tanida, H. Arai, E. Matsubara, Y. Uchimoto and Z. Ogumi, Chemistry of Materials, 25, 1032 (2013).

11. O. J. Borkiewicz, B. Shyam, K. M. Wiaderek, C. Kurtz, P. J. Chupas and K. W. Chapman, Journal of Applied Crystallography, 45, 1261 (2012).

12. B. Key, R. Bhattacharyya, M. Morcrette, V. Seznéc, J.-M. Tarascon and C. P. Grey, Journal of the American Chemical Society, 131, 9239 (2009).

13. M. Letellier, F. Chevallier and F. Béguin, Journal of Physics and Chemistry of Solids, 67, 1228 (2006).

14. J.-C. Jumas, M. Sougrati, A. Perea, L. Aldon and J. Olivier-Fourcade, Hyperfine Interact, 217, 107 (2013).

15. A. Perea, M. T. Sougrati, C. M. Ionica-Bousquet, B. Fraisse, C. Tessier, L. Aldon and J.-C. Jumas, RSC Advances, 2, 2080 (2012).

16. R. A. Dunlap, O. Mao and J. R. Dahn, Physical Review B, 59, 3494 (1999).

17. C. M. Ionica-Bousquet, P. E. Lippens, L. Aldon, J. Olivier-Fourcade and J. C. Jumas, Chemistry of Materials, 18, 6442 (2006).

18. A. Aatiq, M. Menetrier, L. Croguennec, E. Suard and C. Delmas, Journal of Materials Chemistry, 12, 2971 (2002).

19. L. Croguennec, E. Suard, P. Willmann and C. Delmas, Chemistry of Materials, 14, 2149 (2002).

20. O. Bergstrom, A. M. Andersson, K. Edstrom and T. Gustafsson, Journal of Applied Crystallography, 31, 823 (1998).

21. H. Berg and J. O. Thomas, Solid State lonics, 126, 227 (1999).

22. H. Berg, H. Rundlov and J. O. Thomas, Solid State lonics, 144, 65 (2001).

23. M. A. Rodriguez, D. Ingersoll, S. C. Vogel and D. J. Williams, Electrochemical and Solid-State Letters, 7, A8 (2004).

24. M. A. Rodriguez, M. H. Van Benthem, D. Ingersoll, S. C. Vogel and H. M. Reiche, Powder Diffraction, 25, 143 (2010).

25. F. Rosciano, M. Holzapfel, W. Scheifele and P. Novak, Journal of Applied Crystallography, 41, 690 (2008).

26. J. F. Colin, V. Godbole and P. Novak, Electrochemistry Communications, 12, 804 (2010).

27. N. Sharma, V. K. Peterson, M. M. Elcombe, M. Avdeev, A. J. Studer, N. Blagojevic, R. Yusoff and N. Kamarulzaman, Journal of Power Sources, 195, 8258 (2010).

28. N. Sharma and V. K. Peterson, Journal of Solid State Electrochemistry, 16, 1849 (2012).

29. A. Senyshyn, M. J. Muhlbauer, K. Nikolowski, T. Pirling and H. Ehrenberg, Journal of Power Sources, 203, 126 (2012). 
30. X. L. Wang, K. An, L. Cai, Z. L. Feng, S. E. Nagler, C. Daniel, K. J. Rhodes, A. D. Stoica, H. D. Skorpenske, C. D. Liang, W. Zhang, J. Kim, Y. Qi and S. J. Harris, Scientific Reports, 2 (2012).

31. N. Sharma, D. H. Yu, Y. S. Zhu, Y. P. Wu and V. K. Peterson, Chemistry of Materials, 25, 754 (2013).

32. M. Roberts, J. J. Biendicho, S. Hull, P. Beran, T. Gustafsson, G. Svensson and K. Edstrom, Journal of Power Sources, 226, 249 (2013).

33. V. A. Godbole, M. Hess, C. Villevieille, H. Kaiser, J. F. Colin and P. Novak, RSC Advances, 3, 757 (2013).

34. A. V. Dobromyslov and N. I. Taluts, Fiz. Metallov Metalloved., 63, 127 (1987).

35. A. K. Padhi, K. S. Nanjundaswamy and J. B. Goodenough, Journal of The Electrochemical Society, 144, 1188 (1997).

36. M. M. Thackeray, W. I. F. David, P. G. Bruce and J. B. Goodenough, Mater. Res. Bull., 18, 461 (1983).

37. G. Rousse, J. Rodriguez-Carvajal, S. Patoux and C. Masquelier, Chemistry of Materials, 15, 4082 (2003).

38. A. S. Andersson and J. O. Thomas, Journal of Power Sources, 97-98, 498 (2001).

39. P. Gibot, M. Casas-Cabanas, L. Laffont, S. Levasseur, P. Carlach, S. Hamelet, J. M. Tarascon and C. Masquelier, Nature Materials, 7, 741 (2008).

40. A. Yamada, H. Koizumi, S. I. Nishimura, N. Sonoyama, R. Kanno, M. Yonemura, T. Nakamura and Y. Kobayashi, Nature Materials, 5, 357 (2006).

41. C. Delacourt, P. Poizot, J. M. Tarascon and C. Masquelier, Nature Materials, 4, 254 (2005).

42. C. Delacourt, J. Rodriguez-Carvajal, B. Schmitt, J. M. Tarascon and C. Masquelier, Solid State Sciences, 7, 1506 (2005).

43. C. Masquelier, M. Tabuchi, K. Ado, R. Kanno, Y. Kobayashi, Y. Maki, O. Nakamura and J. B. Goodenough, J. Solid State Chem., 123, 255 (1996).

44. J. M. Tarascon, F. Coowar, G. Amatuci, F. K. Shokoohi and D. G. Guyomard, Journal of Power Sources, 54, 103 (1995).

45. J. M. Tarascon and D. Guyomard, Electrochim. Acta, 38, 1221 (1993).

46. J. M. Tarascon, W. R. McKinnon, F. Coowar, T. N. Bowmer, G. Amatucci and D. Guyomard, Journal of The Electrochemical Society, 141, 1421 (1994).

47. D. Guyomard and J. M. Tarascon, Solid State lonics, 69, 222 (1994).

48. R. Kanno, A. Kondo, M. Yonemura, R. Gover, Y. Kawamoto, M. Tabuchi, T. Kamiyama, F. Izumi, C. Masquelier and G. Rousse, Journal of Power Sources, 81-82, 542 (1999).

49. M. Yonemura, A. Yamada, H. Kobayashi, M. Tabuchi, T. Kamiyama, Y. Kawamoto and R. Kanno, Journal of Materials Chemistry, 14, 1948 (2004).

50. A. Yamada, H. Koizumi, N. Sonoyama and R. Kanno, Electrochemical and Solid-State Letters, 8, A409 (2005).

51. H. M. Rietveld, Journal of Applied Crystallography, 2, 65 (1969).

52. J. Rodriguez Carvajal, Physica B, 192, 55 (1993).

53. C. Delmas, M. Maccario, L. Croguennec, F. Le Cras and F. Weill, Nat Mater, 7, 665 (2008).

54. X. Orlhac, C. Fillet, P. Deniard, A. M. Dulac and R. Brec, Journal of Applied Crystallography, 34, 114 (2001). 


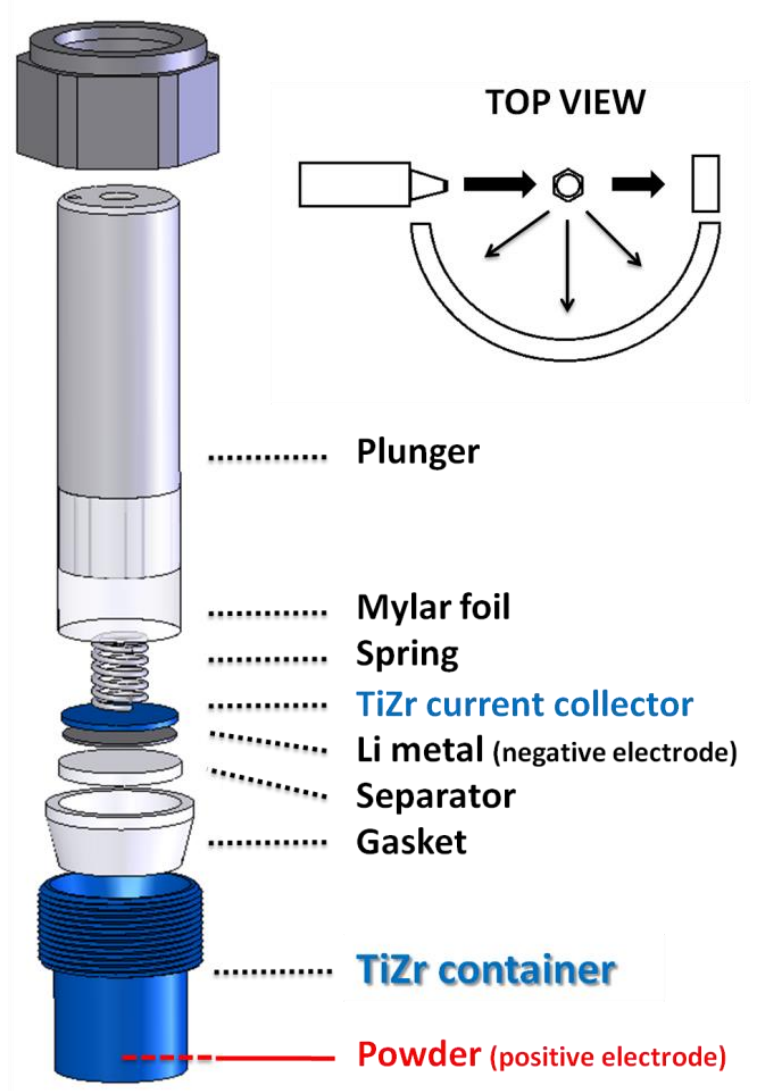

Figure 1: Description of the electrochemical cell designed for in-situ or operando neutron diffraction. 

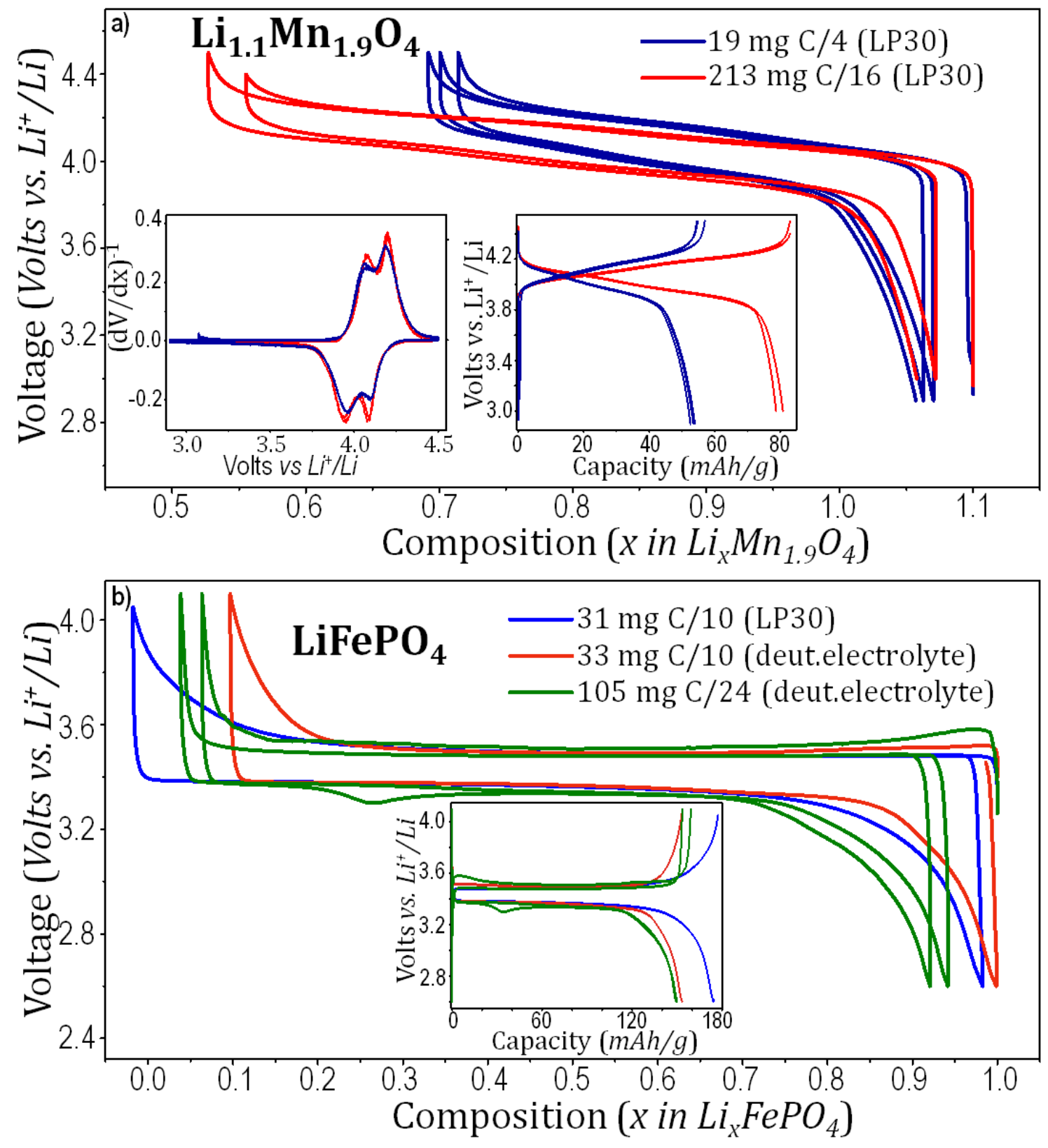

Figure 2: Electrochemical cycles obtained within the in-situ electrochemical cell with two sorts of positive electrode materials: a) the Spinel-type phase $\mathrm{Li}_{1.1} \mathrm{Mn}_{1.9} \mathrm{O}_{2}$ b) the Olivine-type phase $\mathrm{LiFePO}_{4}$. Several tests were performed depending on the active mass, the cycling rate and the electrolyte used (LP30 or a deuterated one). 


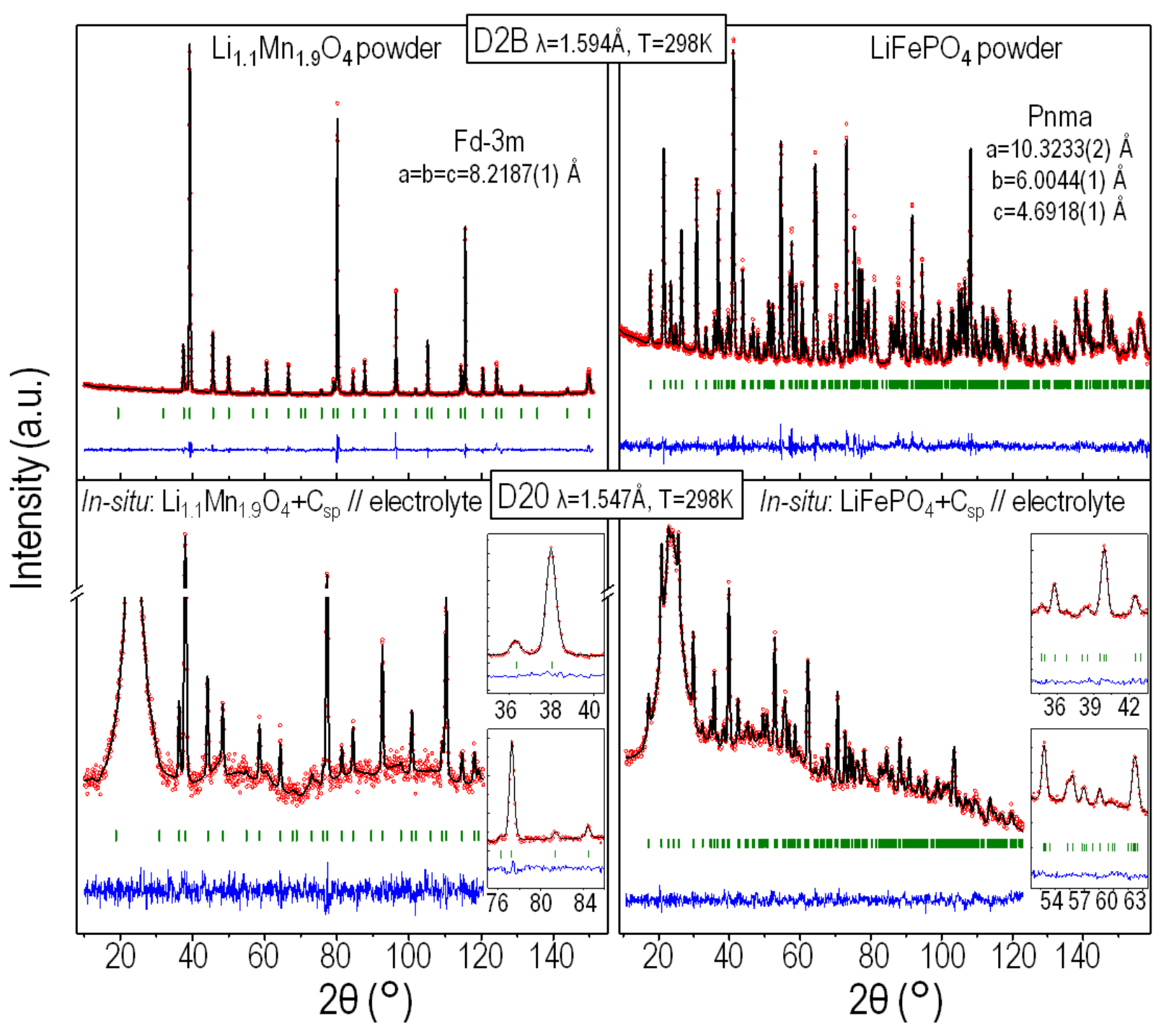

Figure 3: Observed (red dots), calculated (black line) and difference (blue line) plots obtained for the Rietveld refinement of neutron diffraction data recorded: (top) on the diffractometer D2B for the pure powders and (bottom) on the diffractometer D20 for the electrodes within the in-situ lithium cell. 


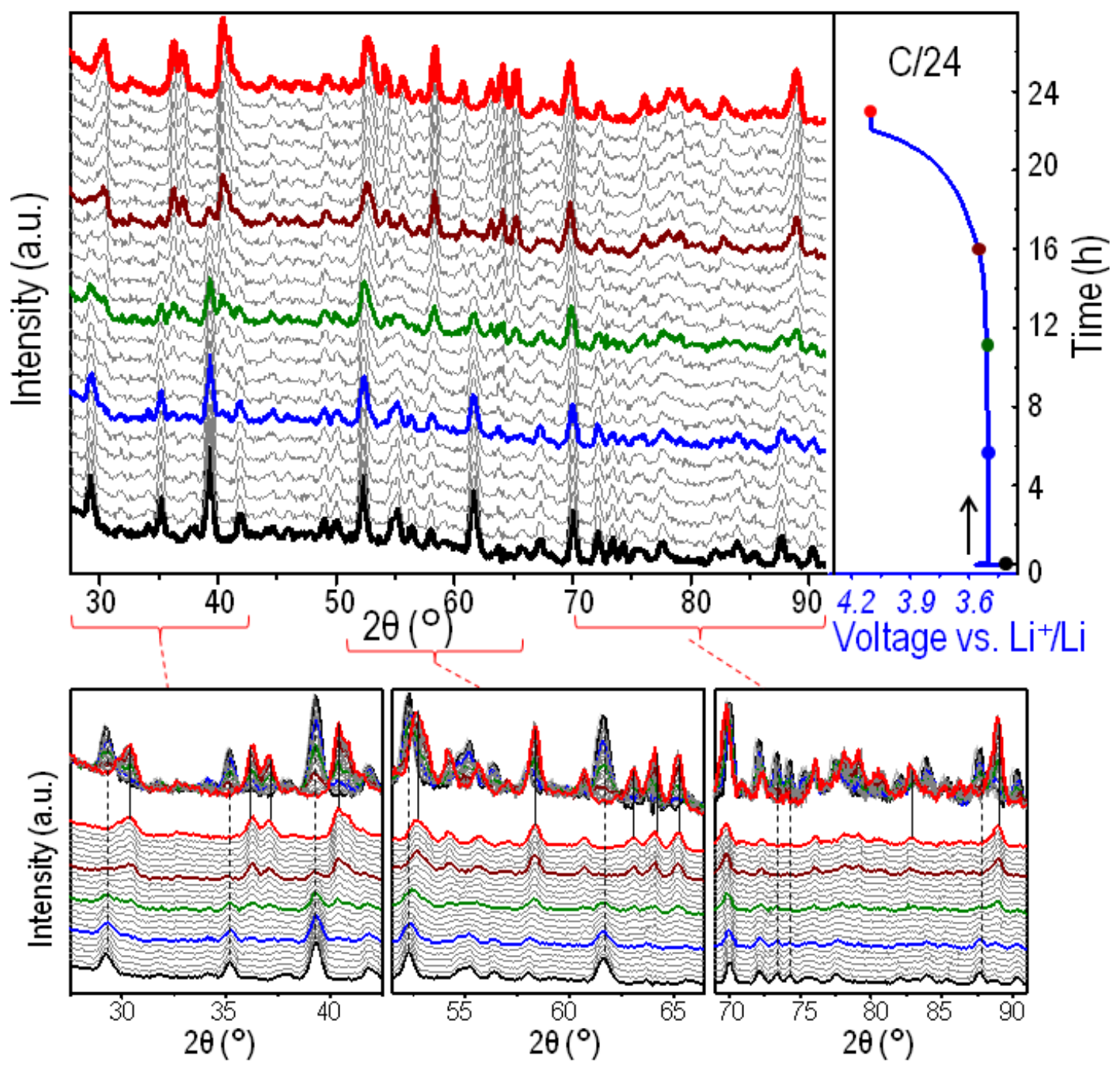

Figure 4: 2D View of collected in-situ ND patterns for the global electrochemical reaction $\mathrm{LiFePO}_{4} \Leftrightarrow \mathrm{FePO}_{4}$ (left) and corresponding galvanostatic cycling data (right). Three different angular ranges are given to highlight the changes in the ND patterns. The ND patterns given in color refer to global compositions for $\mathrm{Li}_{x} \mathrm{FePO}_{4} \mathrm{Close}$ to 1 (black), 0.75 (blue), 0.5 (green), 0.25 (brown) and 0 (red). 


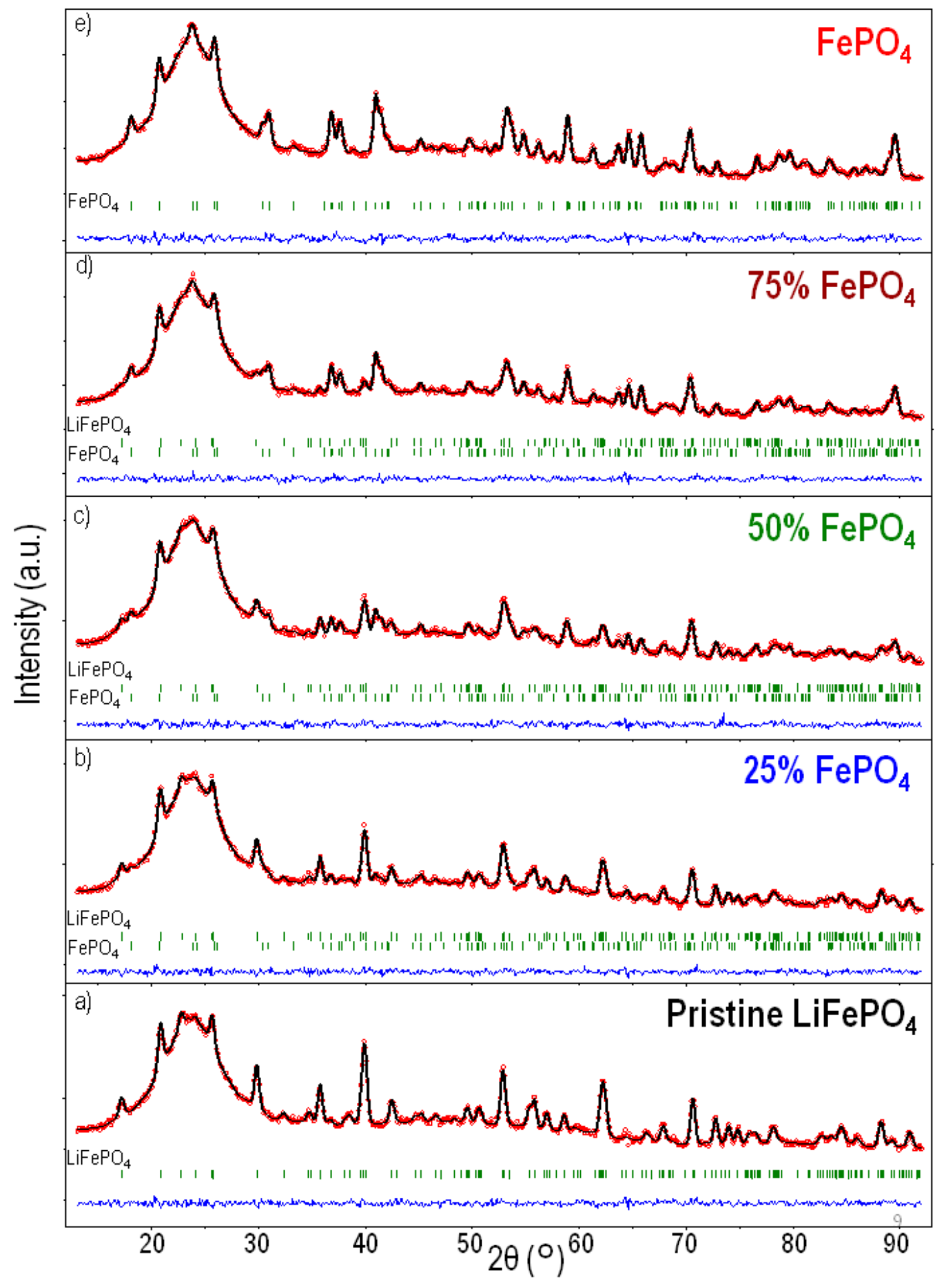

Figure 5: Observed (red dots), calculated (black line) and difference (blue line) plots obtained for the Rietveld refinement of neutron diffraction data recorded within the in-situ lithium cell during $\mathrm{Li}^{+}$extraction from LiFePO ${ }_{4}$. Five compositions are given as examples: (a) pristine $\mathrm{LiFePO}_{4}$, (b) 3/4 $\mathrm{LiFePO}_{4}: 1 / 4 \mathrm{FePO}_{4}$, (c) $1 / 2 \mathrm{LiFePO}_{4}: 1 / 2 \mathrm{FePO}_{4}$, (d) $1 / 4 \mathrm{LiFePO}_{4}: 3 / 4 \mathrm{FePO}_{4}$ and (e) $\mathrm{FePO}_{4}$ 


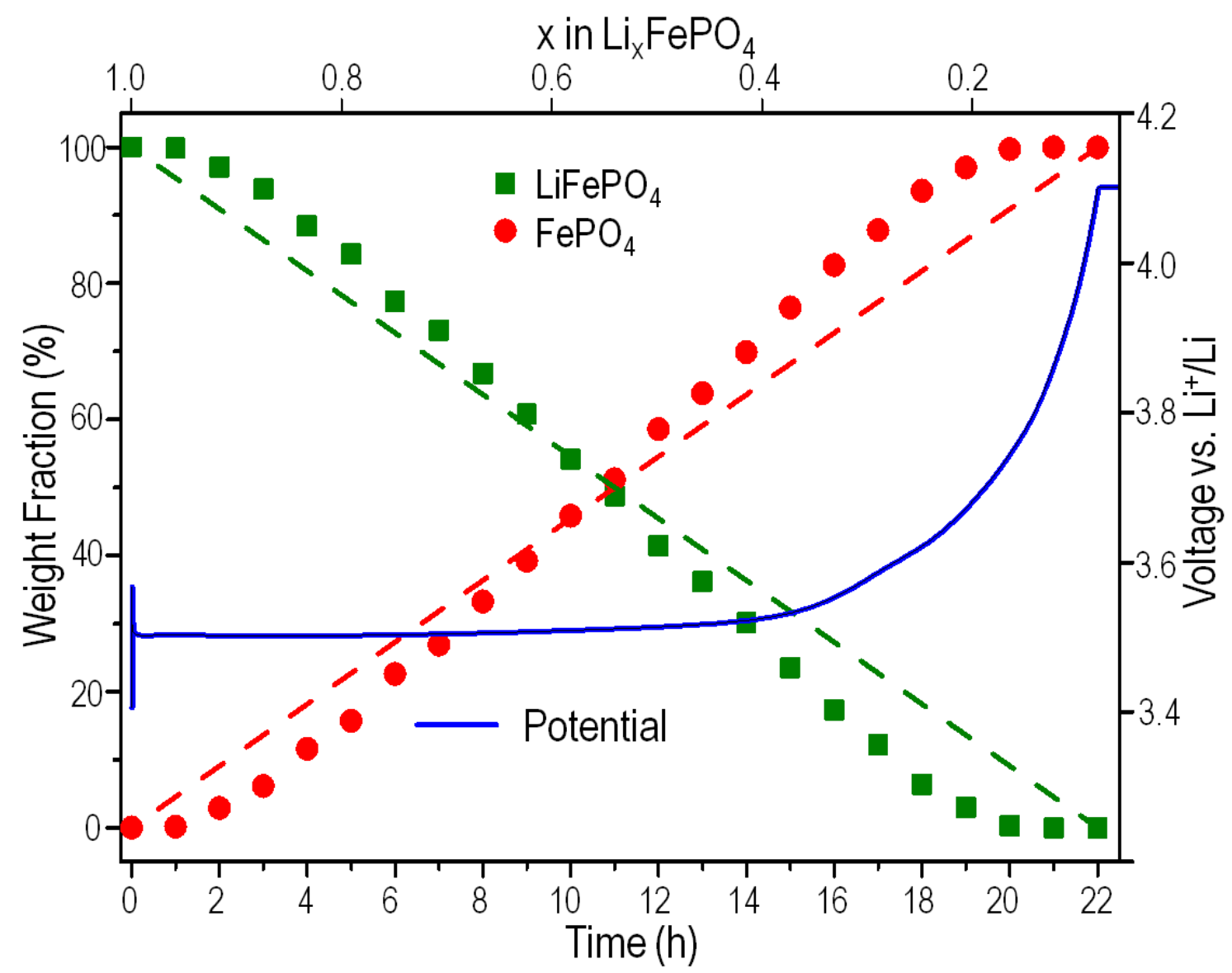

Figure 6: Weight fractions for $\mathrm{LiFePO}_{4}$ and $\mathrm{FePO}_{4}$, within the crystalline part of each composition, determined from neutron diffraction data recorded operando during $\mathrm{Li}^{+}$deintercalation from $\mathrm{LiFePO}_{4}$. 
Table 1: Structural parameters and selected bond lengths obtained after Rietveld refinement of Neutron diffraction data from phase pure $\mathrm{Li}_{1.1} \mathrm{Mn}_{1.9} \mathrm{O}_{4}$ recorded in the in-situ lithium cell on the diffractometer D20 (blue). Comparison with those obtained for the same powder recorded as pure on the diffractometer D2B (black). The same parameters were refined in the 2 cases, except for $B_{\text {iso }}$ that could not be refined for the insitu cell because of the small angular domain (less than $120^{\circ}$ ).

\begin{tabular}{|c|c|c|c|c|c|c|}
\hline \multicolumn{7}{|c|}{ 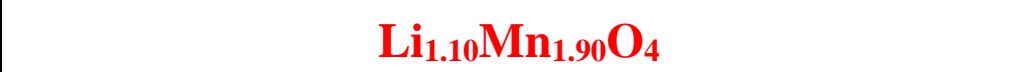 } \\
\hline \multicolumn{7}{|c|}{ S.G. : Fd-3m; $Z=8$} \\
\hline \multirow{2}{*}{\multicolumn{4}{|c|}{$\begin{array}{l}a=b=c=8.2170(6) \AA \\
a=b=c=8.2187(1) \AA\end{array}$}} & \multicolumn{3}{|c|}{$\boldsymbol{R}_{\text {Bragg }}=5.25 \% \chi^{2}=1.41$} \\
\hline & & & & & & \\
\hline & & & & \multicolumn{3}{|c|}{$\underline{D 2 B}: \mathbf{R}_{w p}=13.09 \%$; } \\
\hline \multirow{2}{*}{\multicolumn{4}{|c|}{$\begin{array}{l}V=555.80(8) \AA^{3} ; V / Z=69.47 \AA^{3} \\
V=555.15(1) \AA^{3} ; V / Z=69.39 \AA^{3}\end{array}$}} & \multirow{2}{*}{\multicolumn{3}{|c|}{$R_{\text {Bragg }}=4.79 \% \chi^{2}=3.42$}} \\
\hline & & & & & & \\
\hline \multicolumn{7}{|c|}{ Atomic parameters } \\
\hline \multirow{2}{*}{ Atoms } & \multirow{2}{*}{$\begin{array}{l}\text { Wyckoff } \\
\text { position }\end{array}$} & \multicolumn{3}{|c|}{ Atomic position } & \multirow{2}{*}{ Occ } & \multirow{2}{*}{$\mathbf{B}_{\text {iso }}$} \\
\hline & & $x / a$ & $y / b$ & $z / c$ & & \\
\hline $\mathbf{L i}$ & $8 a$ & 0.375 & 0.375 & 0.375 & $\mathbf{1}$ & 1.3 \\
\hline $\mathbf{L i}(2)$ & 16d & $\mathbf{0}$ & $\mathbf{0}$ & $\mathbf{0}$ & $\begin{array}{l}0.1(2) \\
0.07(6)\end{array}$ & 0.65 \\
\hline Mn & 16d & $\mathbf{0}$ & $\mathbf{0}$ & $\mathbf{0}$ & $\begin{array}{l}1.9(2) \\
1.92(6)\end{array}$ & 0.65 \\
\hline $\mathbf{O}$ & $32 \mathrm{e}$ & $\begin{array}{l}0.2366(5) \\
\mathbf{0 . 2 3 6 8}(1)\end{array}$ & $\begin{array}{l}0.2366(5) \\
0.2368(1)\end{array}$ & $\begin{array}{l}0.2366(5) \\
0.2368(1)\end{array}$ & 1 & 1.07 \\
\hline \multicolumn{7}{|c|}{ Interatomic distances $(\AA)$} \\
\hline \multirow{2}{*}{\multicolumn{3}{|c|}{$\begin{array}{l}M n-O=1.950(4) \\
M n-O=1.953(1)\end{array}$}} & & \multirow{2}{*}{\multicolumn{2}{|c|}{$\begin{array}{l}L i-O=1.970(4) \\
\text { Li-O }=1.967(1)\end{array}$}} & \\
\hline & & & & & & \\
\hline
\end{tabular}


Table 2: Structural parameters obtained after Rietveld refinement of Neutron diffraction data from phase pure $\mathrm{LiFePO}_{4}$ recorded in the in-situ lithium cell on the diffractometer D20 (blue). Comparison with those obtained for the same powder recorded as pure on the diffractometer D2B (black). The same parameters were refined in the 2 cases, except for $B_{\text {iso }}$ that could not be refined for the in-situ cell because of the small angular domain (less than $120^{\circ}$ ).

\begin{tabular}{|c|c|c|c|c|c|c|}
\hline $\begin{array}{l}\text { S.G. : P } \\
a=10.32 \\
a=10.32 \\
V=290.6 \\
V=290.8\end{array}$ & $\begin{array}{l}\text { na; } Z=4 \\
\text { 1) } \AA ; \quad b=6 \text {. } \\
\text { (2) } \AA ; \quad b= \\
\text { 1) } \AA^{3} ; V / Z \\
\AA^{3} ; V / Z\end{array}$ & $\begin{array}{l}\text { 4(1) } \AA ; c= \\
044(1) \AA ; c \\
72.67 \AA^{3} \\
72.71 \AA^{3}\end{array}$ & $\begin{array}{l}\text { 07(7) } \AA ; \\
.6918(1) \AA\end{array}$ & $\begin{array}{l}\underline{D 20}: R_{1} \\
R_{\text {Bragg }}= \\
\underline{\text { D2B: }: ~} \mathbf{R} \\
\mathbf{R}_{\text {Bragg }}=\end{array}$ & $\begin{array}{l}=11 . \\
8 \% \chi\end{array}$ & 2.60 \\
\hline \multicolumn{7}{|c|}{ Atomic parameters } \\
\hline \multirow{2}{*}{ Atoms } & \multirow{2}{*}{$\begin{array}{l}\text { Wyckoff } \\
\text { position }\end{array}$} & \multicolumn{3}{|c|}{ Atomic position } & \multirow{2}{*}{ Occ } & \multirow{2}{*}{$\mathbf{B}_{\text {iso }}$} \\
\hline & & $x / a$ & $y / b$ & $z / c$ & & \\
\hline $\mathbf{L i}$ & $4 a$ & $\mathbf{0}$ & 0 & 0 & 1 & $1.6(4)$ \\
\hline $\mathbf{F e}$ & $4 c$ & $\begin{array}{c}0.282(1) \\
0.2816(4)\end{array}$ & 0.25 & $\begin{array}{c}0.974(4) \\
0.9749(8)\end{array}$ & 1 & $0.63(5)$ \\
\hline $\mathbf{P}$ & $4 c$ & $\begin{array}{c}0.094(2) \\
0.0952(6)\end{array}$ & 0.25 & $\begin{array}{l}0.414(4) \\
0.418(1)\end{array}$ & 1 & $0.43(9)$ \\
\hline $\mathbf{O}(\mathbf{1})$ & $4 c$ & $\begin{array}{c}0.097(2) \\
0.0966(7)\end{array}$ & 0.25 & $\begin{array}{l}0.748(5) \\
0.743(1)\end{array}$ & 1 & $0.8(1)$ \\
\hline $\mathbf{O}(2)$ & $4 c$ & $\begin{array}{c}0.457(2) \\
\mathbf{0 . 4 5 6 6 ( 6 )}\end{array}$ & 0.25 & $\begin{array}{l}0.204(5) \\
0.206(1)\end{array}$ & 1 & $0.7(1)$ \\
\hline $\mathbf{O}(\mathbf{3})$ & $8 d$ & $\begin{array}{c}0.167(2) \\
\mathbf{0 . 1 6 5 5 ( 4 )}\end{array}$ & $\begin{array}{c}0.045(2) \\
\mathbf{0 . 0 4 6 9 ( 6 )}\end{array}$ & $\begin{array}{c}0.285(3) \\
\mathbf{0 . 2 8 3 6}(8)\end{array}$ & 1 & $0.66(6)$ \\
\hline
\end{tabular}


Table 3: Selected bond lengths $(\AA \AA)$ in the structures of $\mathrm{LiFePO}_{4}$ and $\mathrm{FePO}_{4}$ at different key compositions of the phase diagram $\mathrm{xLiFePO}_{4}$. (1-x) $\mathrm{FePO}_{4}$ obtained from ND data recorded operando in the in-situ lithium cell on the diffractometer D20. Expected and refined fractions of each phase are reported in red. Polyhedral distortion is calculated as $\Delta=\frac{1}{N} \sum_{i=1}^{N}\left(\frac{d_{i}-\langle d\rangle}{\langle d\rangle}\right)^{2}$.

\begin{tabular}{|c|c|c|c|c|c|}
\hline \multicolumn{3}{|c|}{$\begin{array}{c}100 \% \mathrm{LiFePO}_{4} \\
a=10.320(1) \AA ; b=6.004(1) \stackrel{\AA}{A} ; c=4.6907(7) \AA ; \quad V=290.68(7) \\
\AA^{3} \\
R_{w p}=16.7 \% R_{B r a g g}=6.51 \% \chi^{2}=1.60\end{array}$} & \multicolumn{3}{|c|}{$0 \% \mathrm{FePO}_{4}$} \\
\hline \multicolumn{3}{|c|}{ Interatomic distances $(\AA) /$ Distortion } & \multicolumn{3}{|c|}{ Interatomic distances $(\AA)$ / Distortion } \\
\hline $\begin{array}{c}\mathrm{Fe}-\mathrm{O1}=2.19(3) \\
\mathrm{Fe}-\mathrm{O} 2=2.10(3) \\
\mathrm{Fe}-\mathrm{O3}(\mathrm{x} 2)= \\
2.05(2) \\
\mathrm{Fe}-\mathrm{O3}(\mathrm{x} 2)= \\
2.25(2) \\
\Delta=16.1 \mathrm{E}-04\end{array}$ & $\begin{array}{c}\mathrm{P}-\mathrm{O} 1=1.57(3) \\
\mathrm{P}-\mathrm{O} 2=1.52(3) \\
\mathrm{P}-\mathrm{O3}(\mathrm{x} 2)=1.56(2) \\
\Delta=1.3 \mathrm{E}-04\end{array}$ & $\begin{array}{c}\text { Li-O1(x2)= } \\
2.16(2) \\
\text { Li-O2(x2)= } \\
2.09(2) \\
\text { Li-O3(x2)= } \\
2.20(2) \\
\Delta=4.2 \mathrm{E}-04\end{array}$ & - & - & - \\
\hline \multicolumn{3}{|c|}{ 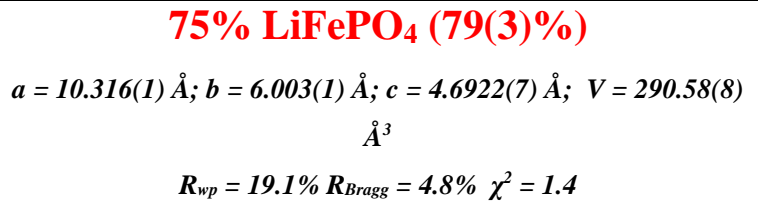 } & \multicolumn{3}{|c|}{$\begin{array}{c}25 \% \mathrm{FePO}_{4}(21(2) \%) \\
a=9.823(6) \stackrel{\AA}{A} ; b=5.796(3) \AA ; \quad c=4.781(3) \AA ; \quad V=272.2(3) \AA^{3} \\
R_{w p}=19.1 \% R_{\text {Bragg }}=9.28 \% \chi^{2}=1.4\end{array}$} \\
\hline \multicolumn{3}{|c|}{ Interatomic distances $(\AA)$ / Distortion } & \multicolumn{3}{|c|}{ Interatomic distances $(\stackrel{\AA}{\mathbf{A}}) /$ Distortion } \\
\hline $\begin{array}{c}\mathrm{Fe}-\mathrm{O} 1=2.18(4) \\
\mathrm{Fe}-\mathrm{O} 2=2.09(4) \\
\mathrm{Fe}-\mathrm{O} 3(\mathrm{x} 2)= \\
2.08(2) \\
\mathrm{Fe}-\mathrm{O3}(\mathrm{x} 2)= \\
2.21(3) \\
\Delta=7.3 \mathrm{E}-04\end{array}$ & $\begin{array}{c}\mathrm{P}-\mathrm{O} 1=1.56(4) \\
\mathrm{P}-\mathrm{O} 2=1.54(5) \\
\mathrm{P}-\mathrm{O3}(\mathrm{x} 2)=1.55(3) \\
\Delta=0.2 \mathrm{E}-04\end{array}$ & $\begin{array}{c}\text { Li-O1(x2)= } \\
2.16(2) \\
\text { Li-O2(x2)= } \\
2.11(2) \\
\text { Li-O3(x2)= } \\
2.20(2) \\
\Delta=2.8 E-04\end{array}$ & $\begin{array}{c}\mathrm{Fe}-\mathrm{O} 1=2.0(1) \\
\mathrm{Fe}-\mathrm{O} 2=2.0(1) \\
\mathrm{Fe}-\mathrm{O3}(\mathrm{x} 2)=1.8(1) \\
\mathrm{Fe}-\mathrm{O3}(\mathrm{x} 2)=2.3(1) \\
\Delta=134.2 \mathrm{E}-04\end{array}$ & $\begin{array}{c}\mathrm{P}-\mathrm{O} 1=1.7(2) \\
\mathrm{P}-\mathrm{O} 2=1.3(2) \\
\mathrm{P}-\mathrm{O3}(\mathrm{x} 2)=1.7(1) \\
\Delta=155.1 \mathrm{E}-04\end{array}$ & - \\
\hline \multicolumn{3}{|c|}{$\begin{array}{l}50 \% \mathrm{LiFePO}_{4}(50(3) \%) \\
\AA ; b=6.004(2) \AA ; c=4.692(1) \AA ; \quad V=290.5(1) \AA^{3} \\
R_{w p}=21.4 \% R_{B r a g g}=7.78 \% \chi^{2}=1.58\end{array}$} & \multicolumn{3}{|c|}{$\begin{array}{c}50 \% \mathrm{FePO}_{4}(50(3) \%) \\
a=9.821(2) \stackrel{\AA}{\circ} ; b=5.793(1) \stackrel{\AA}{*} c=4.777(1) \stackrel{\AA}{*} \quad V=271.8(1) \AA^{3} \\
R_{w p}=21.4 \% R_{\text {Bragg }}=7.59 \% \chi^{2}=1.58\end{array}$} \\
\hline \multicolumn{3}{|c|}{ Interatomic distances $(\AA) /$ Distortion } & \multicolumn{3}{|c|}{ Interatomic distances $(\AA) /$ Distortion } \\
\hline $\begin{array}{c}\mathrm{Fe}-01=2.13(9) \\
\mathrm{Fe}-\mathrm{O} 2=2.16(6) \\
\mathrm{Fe}-03(\mathrm{x} 2)= \\
2.05(4) \\
\text { Fe-O3(x2) } \\
2.22(5) \\
\Delta=9.7 \mathrm{E}-04\end{array}$ & $\begin{array}{c}\mathrm{P}-\mathrm{O} 1=1.60(9) \\
\mathrm{P}-\mathrm{O} 2=1.51(4) \\
\mathrm{P}-\mathrm{O3}(\mathrm{x} 2)=1.56(5) \\
\Delta=4.2 \mathrm{E}-04\end{array}$ & $\begin{array}{c}\text { Li-O1(x2)= } \\
2.15(4) \\
\text { Li-O2(x2)= } \\
2.08(4) \\
\text { Li-O3(x2)= } \\
2.22(4) \\
\Delta=6.8 E-04\end{array}$ & $\begin{array}{c}\mathrm{Fe}-\mathrm{O} 1=1.94(5) \\
\mathrm{Fe}-\mathrm{O} 2=1.89(6) \\
\mathrm{Fe}-\mathrm{O3}(\mathrm{x} 2)= \\
1.93(4) \\
\mathrm{Fe}-03(\mathrm{x} 2)= \\
2.22(5) \\
\Delta=50.2 \mathrm{E}-04\end{array}$ & $\begin{array}{c}\text { P-O1 }=1.59(9) \\
\text { P-O2 }=1.48(9) \\
\text { P-O3(x2) }=1.61(5) \\
\Delta=11.1 E-04\end{array}$ & - \\
\hline \multicolumn{3}{|c|}{$\begin{array}{l}25 \% \mathrm{LiFePO}_{4}(18(2) \%) \\
\stackrel{\circ}{;} b=6.007(4) \AA ; c=4.690(3) \AA ; \quad V=291.3(3) \AA^{3} \\
R_{w p}=19.0 \% R_{B r a g g}=10.6 \% \chi^{2}=1.49\end{array}$} & \multicolumn{3}{|c|}{$\begin{array}{c}75 \% \mathrm{FePO}_{4}(82(3) \%) \\
a=9.820(1) \AA \circ ; b=5.7891(8) \AA ; \quad c=4.7786(7) \AA ; \quad V=271.65(7) \\
\AA^{3} \\
R_{w p}=19.0 \% R_{\text {Bragg }}=5.89 \% \chi^{2}=1.49\end{array}$} \\
\hline \multicolumn{3}{|c|}{ Interatomic distances $(\AA)$ / Distortion } & \multicolumn{3}{|c|}{ Interatomic distances $(\AA)$ / Distortion } \\
\hline
\end{tabular}




\begin{tabular}{|c|c|c|c|c|c|}
\hline $\begin{array}{c}\mathrm{Fe}-\mathrm{O} 1=2.2(1) \\
\mathrm{Fe}-\mathrm{O} 2=2.2(2) \\
\mathrm{Fe}-\mathrm{O3}(\mathrm{x} 2)= \\
1.92(9) \\
\mathrm{Fe}-\mathrm{O3}(\mathrm{x} 2)=2.5(1) \\
\Delta=104.8 \mathrm{E}-04\end{array}$ & $\begin{array}{c}\mathrm{P}-\mathrm{O} 1=1.6(2) \\
\mathrm{P}-\mathrm{O} 2=1.2(2) \\
\mathrm{P}-\mathrm{O3}(\mathrm{x} 2)=1.6(1) \\
\Delta=193.4 \mathrm{E}-04\end{array}$ & $\begin{array}{c}\operatorname{Li}-01(x 2)=2.2(1) \\
\operatorname{Li-O2}(x 2)=2.1(1) \\
\operatorname{Li-O3}(x 2)= \\
2.28(9) \\
\Delta=17.3 E-04\end{array}$ & $\begin{array}{c}\mathrm{Fe}-\mathrm{O} 1=1.91(3) \\
\mathrm{Fe}-\mathrm{O} 2=1.97(3) \\
\mathrm{Fe}-\mathrm{O3}(\mathrm{x} 2)= \\
2.01(2) \\
\mathrm{Fe}-\mathrm{O3}(\mathrm{x} 2)= \\
2.16(3) \\
\Delta=21.9 \mathrm{E}-04\end{array}$ & $\begin{array}{c}\mathrm{P}-\mathrm{O} 1=1.54(4) \\
\mathrm{P}-\mathrm{O} 2=1.45(4) \\
\mathrm{P}-\mathrm{O3}(\mathrm{x} 2)=1.58(3) \\
\Delta=11.6 \mathrm{E}-04\end{array}$ & - \\
\hline \multicolumn{3}{|c|}{$\begin{array}{c}0 \% \mathrm{LiFePO}_{4} \\
--\end{array}$} & \multicolumn{3}{|c|}{$\begin{array}{c}100 \% \mathrm{FePO}_{4} \\
a=9.820(1) \AA ; \quad b=5.7892(6) \AA ; \quad c=4.7790(6) \AA ; \quad V=271.69(5) \\
\AA^{3} \\
R_{w p}=16.7 \% R_{B r a g g}=5.30 \% \chi^{2}=1.79\end{array}$} \\
\hline \multicolumn{3}{|c|}{ Interatomic distances $(\AA) /$ Distortion } & \multicolumn{3}{|c|}{ Interatomic distances $(\AA)$ / Distortion } \\
\hline- & - & - & $\begin{array}{c}\mathrm{Fe}-\mathrm{O1}=1.92(2) \\
\mathrm{Fe}-\mathrm{O} 2=1.93(2) \\
\mathrm{Fe}-\mathrm{O3}(\mathrm{x} 2)= \\
2.02(2) \\
\mathrm{Fe}-\mathrm{O3}(\mathrm{x} 2)= \\
2.15(2) \\
\Delta=20.0 \mathrm{E}-04\end{array}$ & $\begin{array}{c}\mathrm{P}-\mathrm{O} 1=1.53(3) \\
\mathrm{P}-\mathrm{O} 2=1.51(3) \\
\mathrm{P}-\mathrm{O3}(\mathrm{x} 2)=1.58(2) \\
\Delta=3.7 \mathrm{E}-04\end{array}$ & - \\
\hline
\end{tabular}


Table S1: Structural parameters obtained after Rietveld refinement of Neutron diffraction data from phase pure $\mathrm{LiFePO}_{4}$ recorded in the in-situ lithium cell on the diffractometer D20 for one hour (blue) and for 30 minutes (black). The same parameters were refined in the 2 cases, except for $B_{\text {iso }}$ that could not be refined for the in-situ cell because of the small angular domain (less than $120^{\circ}$ ).

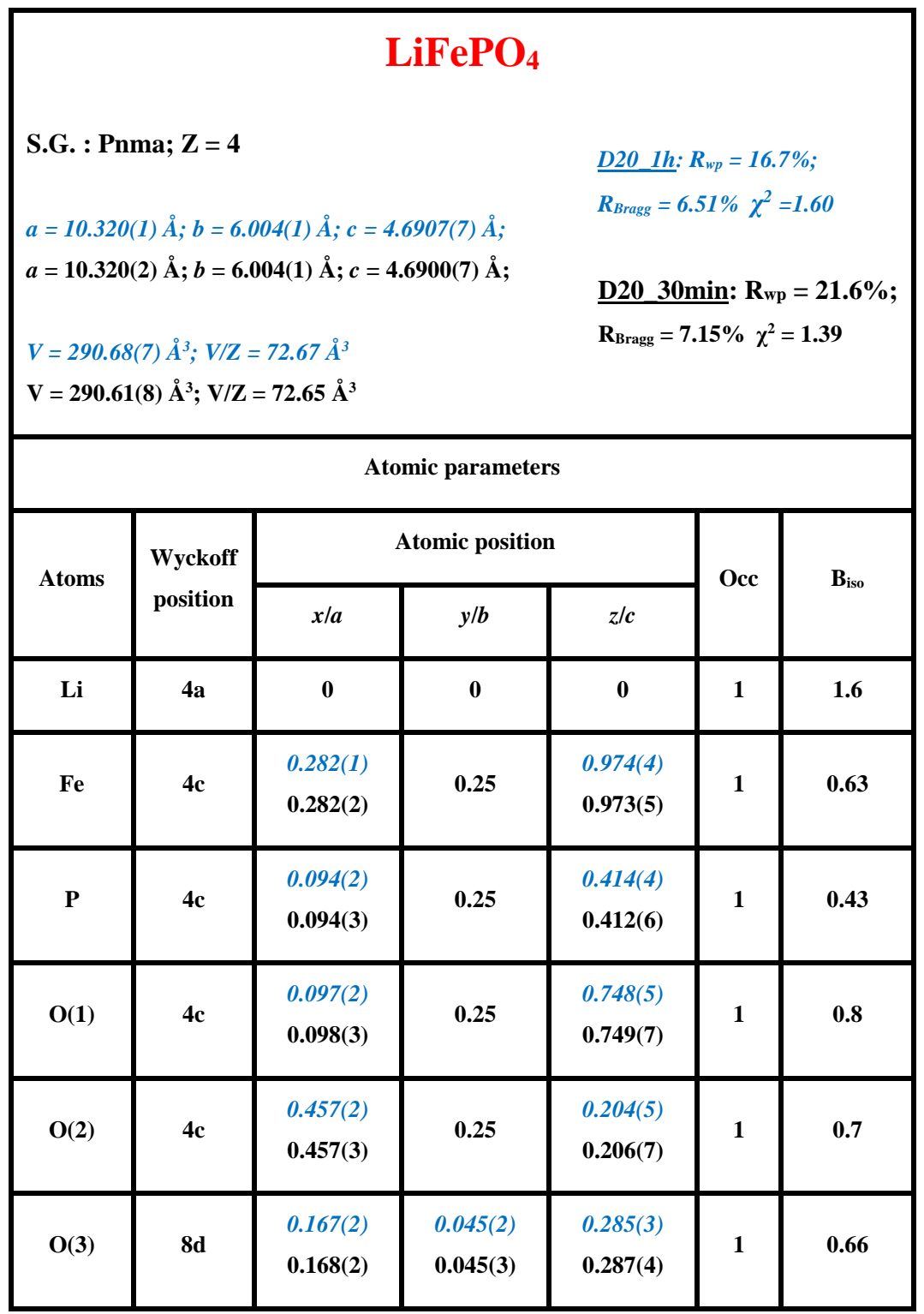

